Jurnal Pendidikan dan Pembelajaran Kimia, Vol. 8, No. 2, Tahun 2019.

Program Studi Kimia. FKIP. Universitas Lampung

https://jurnal.fkip.unila.ac.id/

\title{
Pengaruh Isu Sosio-Saintifk dalam Meningkatkan Kemampuan Berpikir Kritis pada Materi Larutan Elektrolit dan Non-Elektrolit
}

\author{
Yunisa Sari Pandela*, Sunyono, Ratu Betta Rudibyani \\ FKIP Universitas Lampung, Jl. Prof. Dr. Soemantri Brojonegoro No. 1 \\ *email: yunisa.pandela@gmail.com, Telp: +6285384414910

Abstract: The Effect of Socio-Scientific Issues in Improving Critical Thinking Ability on Electrolyte and Non-Electrolyte Solutions. This research was aimed to describe the effect of socio-scientific issues in improving critical thinking ability on electrolyte and non-electrolyte solutions. The cluster random sampling technique was used for the selection of samples, obtained XIPA 1 as experimental class and XIPA 4 as control class. The method is quasi-experimental design with a pretest posttest control group design. The effect of socioscientific issues was analyzed by the differences of two averages on $n$-Gain and the effect size test. The results of the study showed that the average $n$-Gain of students' critical thinking ability in the experimental class was' high ', and the effect size was' large'. The conclusion of this research is that socioscientific issues based learning has a positive effect in improving critical thinking ability in electrolyte and non-electrolyte solutions material.

Keywords: socioscientific issues, critical thinking ability, electrolyte and non-electrolyte solutions

Abstrak: Pengaruh Isu Sosiosaintifk dalam Meningkatkan Kemampuan Berpikir Kritis pada Materi Larutan Elektrolit dan Non-Elektrolit. Penelitian ini bertujuan untuk mendeskripsikan pengaruh isu sosiosaintifik dalam meningkatkan kemampuan berpikir kritis pada materi larutan elektrolit dan non-elektrolit. Teknik cluster random sampling digunakan untuk pemilihan sampel, diperoleh kelas X IPA 1 sebagai kelas eksperimen dan kelas X IPA 4 sebagai kelas kontrol. Metode dalam penelitian ini yaitu kuasi eksperimen dengan desain penelitian pretest posttest control group design. Pengaruh isu sosiosaintifik dianalisis menggunakan uji perbedaan dua rata-rata pada nGain dan uji effect size. Hasil penelitian menunjukkan bahwa rata-rata n-Gain kemampuan berpikir kritis siswa pada kelas eksperimen berkriteria 'tinggi', dan effect size 'besar'. Kesimpulan penelitian ini yaitu pembelajaran berbasis isu sosiosaintifik berpengaruh positif dalam meningkatkan kemampuan berpikir kritis pada materi larutan elektrolit dan non elektrolit.

Kata kunci: isu sosisaintifik, kemampuan berpikir kritis, larutan elektrolit dan nonelektrolit 


\section{PENDAHULUAN}

Sains selalu mengalami perkembangan, begitu pula tujuan pendidikan sains yang selalu berkembang dan berusaha memenuhi kebutuhan masyarakat (Osborne, 2005). Menurut Holbrook dan Rannikmae (2009), perkembangan sains dan teknologi yang pesat dewasa ini, selain memberikan manfaat untuk memenuhi kebutuhan manusia, ternyata juga memunculkan banyak permasalahan baru terkait etika, moral dan isu-isu global yang justru dapat mengancam martabat dan kelangsungan hidup manusia. Masalah yang berhubungan dengan sains serta melibatkan komponen moral dan etika ini disebut isu sosiosantifik (Zeidler, 2005).

Menurut hasil studi Program for International Student Assesment (PISA) tahun 2015 pada aspek sains, Indonesia mendapatkan peringkat ke 62 dari 71 negara dengan skor 403, dimana rata-rata skor PISA tahun 2015 pada aspek sains sebesar 493. Perolehan skor yang diperoleh Indonesia pada aspek sains masih jauh di bawah rata-rata, sedangkan negara-negara lain seperti Singapura mendapatkan skor 556, Cina mendapat skor 529 dan Korea mendapatkan skor 516 (OECD, 2016). Berdasarkan data tersebut dapat disimpulkan bahwa Indonesia memiliki sumber daya manusia yang lemah, terutama di bidang pendidikan sains.

Salah satu upaya dalam bidang pendidikan yang dapat dilakukan untuk mencetak sumber daya manusia yang berkualitas yaitu dengan membiasakan membentuk budaya berpikir kritis pada siswa dalam proses pembelajarannya. Berpikir kritis adalah kemampuan berpikir reflektif yang berfokus pada pola pengambilan keputusan tentang apa yang harus diyakini dan harus dilakukan (Ennis 2011).

Kenyataan di sekolah, pendidkan sains dalam hal ini kimia belum banyak yang berorientasi ke arah pembiasaan dan peningkatan kecakapan kemampuan berpikir tingkat tinggi (berpikir kritis), tetapi masih menitikberatkan pada hasil belajar kognitif tingkat rendah (Bassham, 2010).

Pembelajaran yang seperti ini mengakibatkan siswa tidak memperoleh pengalaman untuk mengembangkan kemampuan berpikir kritisnya. Hal ini berdampak pada mutu lulusan pendidikan yang rendah, terutama dalam hal kompetensi sains dan penerapannya dalam kehidupan sehari-hari, serta mengakibatkan tidak mampu bersaing dengan bangsa lain (PISA 2009).

Berdasarkan permasalahan di atas, perlu adanya upaya untuk menyelesaikan permasalahan tersebut yaitu melalui pembelajaran berbasis isu sosiosaintifik yang berhubungan langsung dengan kehidupan sehari-hari siswa, sehingga diharapkan dapat membantu meningkatkan kemampuan berpikir kritis siswa. Isu sosiosaintifik (ISS) merupakan representasi isu-isu atau persoalan dalam kehidupan sosial yang secara konseptual berkaitan erat dengan sains dengan solusi jawaban yang relatif atau tidak pasti. Penelitian relevan yang telah dilakukan dengan permasalahan tersebut adalah penelitian Wilsa (2017) menyatakan bahwa model pembelajaran Problem Based Learning berbasis isu sosiosaintifik berpengaruh terhadap pengembangan kemampuan berpikir 
kritis, komunikasi tertulis dan verbal serta hasil belajar kognitif pada konsep keanekaragaan hayati. Selain itu, penelitian yang dilakukan oleh Lathifah dan Susilo (2015) menyatakan bahwa pendekatan pembelajaran isu sosiosaintifik dapat meningkatkan kemampuan berpikir kritis. Hasil penelitian tersebut menunjukkan bahwa pendekatan pembelajaran berbasis isu sosiosaintifik berperan dalam kemampuan berpikir kritis peserta didik. Didukung pula oleh penelitian Putriana (2018) menyimpulkan bahwa pembelajaran menggunakan isu sosiosaintifik dapat meningkatkan metakognisi siswa.

Salah satu pendekatan dalam pembelajaran yang menghadirkan isu-isu sosial berkaitan dengan sains yang ada di masyarakat adalah isu sosiosaintifik (Yuliastini, 2016). Penggunaan pendekatan ISS dalam pembelajaran dalam hal ini kimia berfungsi untuk mengatasi implikasi masyarakat dari ilmu pengetahuan dan teknologi, serta memasukkan filosofi pribadi dan sistem kepercayaan siswa. Isu sosiosaintifik dalam pembelajaran mempunyai beberapa manfaat yaitu, menumbuhkan literasi sains pada peserta didik sehingga dapat menerapkan pengetahuan sains berbasis bukti dalam kehidupan sehari-hari, (2) terbentuknya kesadaran sosial dimana peserta didik dapat melakukan refleksi mengenai hasil penalaran mereka, (3) mendorong kemampuan argumentasi terhadap proses berpikir dan bernalar ilmiah terhadap suatu fenomena yang ada di masyarakat, dan (4) meningkatkan kemampuan berpikir kritis yang meliputi menganalisis, membuat kesimpulan, memberikan penjelasan, mengevaluasi, menginterpretasi, dan melakukan self-regulation. Isu sosiosaintifik sangat berkaitan erat dengan kemampuan berpikir kritis karena dalam proses pembelajarannya siswa diharuskan secara aktif mulai dari menganalisis isu-isu yang ada di masyarakat sampai membuat kesimpulan (Zeidler, 2005).

Contoh masalah yang dapat dibahas adalah mengenai pencemaran lingkungan yang diakibatkan oleh limbah aki dan penggunaan alat setrum untuk menangkap belut. Kerusakan lingkungan akibat limbah aki merupakan isu sosiosaintifik, karena terkait dengan konsep-konsep sains khususnya kimia. Isu ini berkaitan dengan konsep kimia yang dipelajari oleh siswa kelas X SMA yaitu larutan elektrolit dan non-elektrolit.

Berdasarkan pemikiran di atas, dalam upaya meningkatkan kemampuan berpikir kritis siswa khususnya pada materi larutan elektrolit dan non elektrolit, maka dilakukan penelitian dengan judul "Pengaruh Pembelajaran Berbasis Isu Sosiosaintifik dalam Meningkatkan kemampuan Berpikir Kritis Siswa pada Materi Larutan Elektrolit dan Non Elektrolit".

\section{METODE}

\section{Metode Penelitian}

Metode penelitian yang digunakan dalam penelitian ini adalah kuasi eksperimen dengan Pretest Posttest Control Group Design (Fraenkel, 2012).

\section{Waktu dan Tempat Penelitian}

Penelitian ini dilaksanakan di salah satu sekolah yang terletak di Bandar Lampung. Waktu pelaksanaan penelitian dilakukan 
pada tanggal 17 Januari 2019 dan berakhir pada tanggal 15 Februari 2019.

\section{Populasi dan Sampel}

Populasi dalam penilitian ini yaitu seluruh siswa kelas X IPA pada salah satu sekolah yang terletak di Bandar Lampung tahun ajaran 2018/2019 yang tersebar dalam 8 kelas. Pengambilan sampel dilakukan dengan teknik cluster random sampling. Pengambilan sampel dilakukan secara acak sehingga mendapatkan 2 kelas penelitian yaitu $\mathrm{X}$ IPA 1 sebagai kelas eksperimen dilakukan pembelajaran berbasis isu sosiosaintifik dan X IPA 4 sebagai kelas kontrol dilakukan pembelajaran tanpa menggunakan isu sosiosaintifik.

\section{Prosedur}

Prosedur pelaksanaan penelitian terdiri dari tahap persiapan yaitu melakukan observasi ke sekolah, menentukan populasi dan sampel penelitian, mempersiapkan perangkat pembelajaran dan instrumen penelitian, serta melakukan uji validitas dan reliabilitas terhadap instrumen tes yang diuji pada siswa kelas XI IPA yang telah menerima materi larutan elektrolit dan non elektrolit. Tahap pelaksanaan yaitu melakukan pretes pada kelas eksperimen dan kelas kontrol untuk mengetahui kemampuan berpikir kritis awal siswa, pelaksanaan penelitian di dua kelas, yaitu di kelas eksperimen menggunakan pembelajaran isu sosiosaintifik dan kelas kontrol tanpa menggunakan pembelajran isu sosiosaintifik, kemudian postes pada kelas eksperimen dan kelas kontrol untuk mengukur peningkatan kemampuan berpikir kritis siswa. Tahap akhir penelitian berupa analisis data, pembahasan dan kesimpulan.

\section{Perangkat Pembelajaran dan Instrumen Penelitian}

Perangkat pembelajaran yang digunakan dalam penelitian ini yaitu silabus, RPP, dan LKPD berbasis isu sosiosaintifik.

Instrumen yang digunakan dalam penelitian ini yaitu tes tertulis berupa soal pretes postes yang terdiri dari 6 butir soal uraian. Lembar penilaian yang terdiri dari lembar observasi keterlaksanaan pengaruh pembelajaran berbasis isu sosiosaintifik dan lembar pengamatan aktivitas siswa.

\section{Teknik Analisis Data}

Analisis data yang dilakukan dalam penelitian ini dilakukan uji validitas dan reliabilitas instrumen serta ukuran pengaruh. Analisis data yang telah diperoleh dihitung menggunakan software SPSS 23 for Windows.

Uji validitas dihitung dengan SPSS versi 23 for Windows. Taraf signifikan $5 \%$, dengan kriteria soal dikatakan valid jika $r$ hitung $\geq r$ tabel dan nilai sig (p) dari Kolmogorov Smirnov dan Shapiro-Wilk $>0,05$.

Uji reliabilitas dilakukan dengan melihat Alpha Cronbach's yang dihitung dengan SPSS versi 23 for Windows. Kemudian diinterpretasikan dengan derajat reliabilitas $\left(\mathrm{r}_{11}\right)$. Kriteria reliabilitas soal jika nilai Alpha Cronbach's $\geq \mathrm{r}$ tabel.

Nilai pretes dan postes pada penilaian kemampuan berpikir kritis secara operasional dirumuskan sebagai berikut:

$$
\text { Nilai siswa }=\frac{\text { jumlah skor yang diperoleh }}{\text { jumlah skor maksimal }} \times 100
$$


Kemudian data yang diperoleh dilakukan dengan perhitungan $n$ Gain. Peningkatan kemampuan berpikir kritis siswa ditunjukkan melalui n-Gain. Perhitungan n-Gain dilakukan dengan menggunakan rumusan Hake (1998) dengan kriteria sebagai berikut:

Tabel 1. Kriteria $n$-Gain

\begin{tabular}{ll}
\hline Rata-rata $n$-Gain & Kriteria \\
\hline $\mathrm{g}>0,7$ & Tinggi \\
$0,7>\mathrm{g} \geq 0,3$ & Sedang \\
$\mathrm{g}<0,3$ & Rendah \\
\hline
\end{tabular}

Pengaruh pembelajaran berbasis isu sosiosaintifik pada materi larutan elektrolit dan non elektrolit didukung dengan data keterlaksanaan pembelajaran berbasis isu sosiosaintifik dan data aktivitas siswa selama pembelajaran yang dinilai oleh dua observer, yaitu guru mitra dan rekan penelitian.

Analisisnya menggunakan rumus menurut Sudjana (2005) sebagai berikut:

$$
\% \mathrm{Ji}=\frac{\sum \mathrm{Ji}}{N} x 100 \%
$$

Dimana \%Ji adalah persentase ketercapaian dari skor ideal untuk setiap aspek pengamatan pada pertemuan ke-i, $\Sigma \mathrm{ji}$ adalah jumlah skor setiap aspek pengamatan yang diberikan oleh pengamat pada pertemuan ke-i, $\mathrm{N}$ adalah skor maksimal.

Tabel 2. Kriteria Tingkat Ketercapaian Pelaksanaan Pembelajaran

\begin{tabular}{ll}
\hline \multicolumn{1}{c}{ Persentase } & \multicolumn{1}{c}{ Kriteria } \\
& \\
\hline $80,1 \%-100 \%$ & Sangat Tinggi \\
$60,1 \%-80 \%$ & Tinggi \\
$40,1 \%-60 \%$ & Sedang \\
$20,1 \%-40 \%$ & Rendah \\
$0,0 \%-20 \%$ & Sangat rendah \\
\hline & (Arikunto, 2006).
\end{tabular}

Tebel 2 menunjukkan tafsiran data keterlaksanaan pembelajaran berbasis isu sosiosaintifik.

Kemudian mengamati aktivitas siswa selama pembelajaran berlangsung diukur dengan menggunakan lembar observasi oleh dua observer. Analisis deskriptif terhadap aktivitas siswa dalam pembelajaran dilakukan dengan langkah-langkah sebagai berikut:

1. Menghitung persentase aktivitas siswa untuk setiap pertemuan.

2. Menghitung jumlah persentase aktivitas siswa yang relevan dan yang tidak relevan dengan pembelajaran untuk setiap pertemuan dan menghitung rataratanya, kemudian menafsirkan data dengan menggunakan tafsiran harga persentase sebagaimana pada tabel 3 .

Tabel 3. Kriteria Aktivitas Siswa

\begin{tabular}{ll}
\hline Persentase & Kriteria \\
\hline $80,1 \%-100 \%$ & Sangat Tinggi \\
$60,1 \%-80 \%$ & Tinggi \\
$40,1 \%-60 \%$ & Sedang \\
$20,1 \%-40 \%$ & Rendah \\
$0,0 \%-20 \%$ & Sangat rendah \\
\hline
\end{tabular}

(Ratumanan dalam Sunyono, 2012).

Pengujian hipotesis pada penelitian ini menggunakan uji perbedaan dua rata-rata (uji-t). Sebelum melakukan uji-t, dilakukan uji prasyarat yaitu uji normalitas dan homogenitas terlebih dahulu untuk mengetahui apakah sampel berasal dari populasi yang berdistribusi normal dan homogen dengan menggunakan aplikasi SPSS statistic 23 for Windows.

Kriteria dari uji independent sampel t-test terima $\mathrm{H}_{0}$ jika nilai sig. (2-tailed) $<0,05$, berarti bahwa ratarata $n$-Gain kemampuan berpikir 
kritis siswa pada materi larutan elektrolit dan non elektrolit yang menggunakan pembelajaran berbasis isu sosiosaintifik lebih tinggi daripada rata-rata n-Gain kemampuan berpikir kritis yang menggunakan model pembelajaran konvensional dan terima $\mathrm{H}_{1}$ apabila nilai sig. (2-tailed) $>0,05$, yang berarti bahwa rata-rata n-Gain kemampuan berpikir kritis siswa pada materi larutan elektrolit dan non elektrolit yang menggunakan pembelajaran berbasis isu sosiosaintifik lebih rendah daripada rata-rata $n$-Gain kemampuan berpikir kritis yang menggunakan model pembelajaran konvensional.

Nilai t hitung yang diperoleh dari uji independent sampel t-test terhadap nilai pretes-postes dari kelas kontrol dan kelas eksperimen, dilakukan perhitungan lebih lanjut untuk mengetahui seberapa besar pengaruh (effect size) pembelajaran berbasis isu sosiosaintifik dalam meningkatkan kemampuan berpikir kritis siswa pada materi larutan elektrolit dan non elektrolit, yaitu dengan uji ukuran pengaruh (effect size) menurut Abujahjouh (2014) dengan rumus:

$$
\mu^{2}=\frac{\mathrm{t}^{2}}{\mathrm{t}^{2}+d f}
$$

dengan $\mu$ adalah effect size, $\mathrm{t}$ adalah $\mathrm{t}$ hitung dari uji-t, dan df adalah derajat kebebasan. Data yang diperoleh dikelompokkan sesuai dengan kriteria effect size menurut Dincer (2015) yang ditunjukkan pada Tabel 4.

\begin{tabular}{ll}
\multicolumn{2}{l}{ Tabel 4. Kriteria Effect Size } \\
\hline Effect Size & Kriteria \\
\hline$\mu \leq 0,15$ & Efek diabaikan \\
$0,15<\mu \leq 0,40$ & Efek kecil \\
$0,40<\mu \leq 0,75$ & Efek sedang \\
$0,75<\mu \leq 1,10$ & Efek besar \\
$\mu>1,10$ & Efek sangat besar \\
\hline
\end{tabular}

\section{HASIL DAN PEMBAHASAN}

\section{Uji Validitas dan Reliabilitas Instrumen}

Uji validitas dilakukan pada instrumen tes berupa soal pretes postes kemampuan berpikir kritis yang terdiri dari 6 butir soal uraian tentang materi larutan elektrolit dan non elektrolit. Adapun hasil dari uji validitas soal pretes postes kemampuan berpikir kritis dapat dilihat pada Tabel 5.

Tabel 5. Validitas soal pretes postes

\begin{tabular}{cccc}
\hline $\begin{array}{c}\text { Butir } \\
\text { Soal }\end{array}$ & $\begin{array}{c}\text { Koefisien } \\
\text { Korelasi }\end{array}$ & $\mathbf{r}_{\text {tabel }}$ & Keterangan \\
\hline & & & \\
1a & 0,6 & 0,4438 & Valid \\
1b & 0,474 & 0,4438 & Valid \\
$2 \mathrm{a}$ & 0,606 & 0,4438 & Valid \\
$2 \mathrm{~b}$ & 0,586 & 0,4438 & Valid \\
3 & 0,759 & 0,4438 & Valid \\
4 & 0,746 & 0,4438 & Valid \\
5 & 0,516 & 0,4438 & Valid \\
6 & 0,676 & 0,4438 & Valid \\
\hline
\end{tabular}

Berdasarkan Tabel 5. keenam butir soal dinyatakan valid karena pretes postes kemampuan berpikir kritis siswa memiliki nilai koefisien korelasi ( $\mathrm{r}_{\text {hitung }}$ ) yang lebih besar dari nilai $r_{\text {tabel. }}$.

Uji reliabilitas pada soal pretes postes kemampuan berpikir kritis diperoleh nilai Alpha Cronbach sebesar 0,747. Soal pretes postes tersebut dikatakan reliabel dengan kriteria tinggi. Berdasarkan hasil uji validitas dan reliabilitas tersebut, maka instrumen tes tersebut layak digunakan sebagai alat untuk mengukur kemampuan berpikir kritis.

Setelah selesai tahap pelaksanaan penelitian, kemudian diperoleh data-data pada kelas eksperimen dan kelas kontrol. Datadata yang diperoleh yaitu nilai pretes 
dan postes. Pengolahan atau analisis data dilakukan secara statistika.

Kemampuan berpikir kritis siswa diukur menggunakan soal pretes dan postes tentang materi larutan elektrolit dan non elektrolit yang diberikan kepada seluruh siswa kelas X IPA 1 (kelas eksperimen) dan X IPA 4 (kelas kontrol). Peningkatan kemampuan berpikir kritis siswa ditunjukkan melalui $n$ Gain, yaitu selisih antara nilai postes dan nilai pretes yang dihitung berdasarkan rumus Hake (1998). Terdapat 12 indikator kemampuan berpikir kritis, namun dalam penelitian ini tidak digunakan semua indikator karena waktu penelitian yang terbatas. Pada penelitian ini hanya menggunakan 6 indikator kemampuan berpikir kritis, baik pada kelas kontrol maupun kelas eksperimen seperti yang tertera pada Gambar 1.

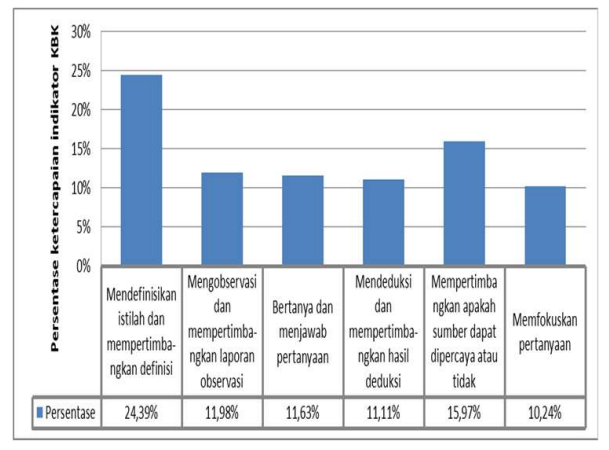

Gambar 1. Persentase ketercapaian setiap indikator kemampuan berpikir kritis siswa pada kelas eksperimen.

Berdasarkan Gambar 1, menunjukkan bahwa pada kelas eksperimen (kelas X IPA 1), kemampuan berpikir kritis siswa menggunakan pembelajaran berbasis isu sosiosaintifik secara keseluruhan sudah terlaksana dengan baik, hal ini dapat dilihat dari persentase ketercapaian setiap indikator kemampuan berpikir kritis. Pada penelitian ini, indikator kemampuan berpikir kritis siswa yang sudah terlatih dengan baik yaitu pada indikator mendefinisikan istilah dan mempertimbangkan definisi, dimana pada indikator tersebut memiliki persentase sebesar 24,39\%, sedangkan indikator kemampuan berpikir kritis siswa yang belum terlatih dengan baik yaitu pada indikator memfokuskan pertanyaan, dimana pada indikator tersebut memiliki persentase sebesar $10,24 \%$.

Kemudian diperoleh rata-rata nilai pretes dan postes pada kelas kontrol dan kelas eksperimen. Adapun rata-rata nilai pretes dan postes kemampuan berpikir kritis siswa disajikan dalam Gambar 2.

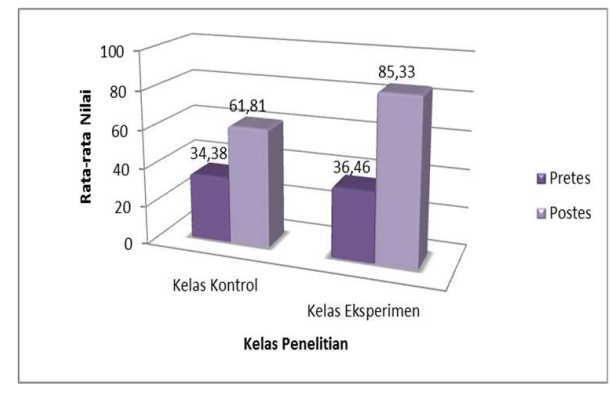

Gambar 2. Rata-rata nilai pretes dan postes kemampuan berpikir kritis siswa kelas kontrol dan kelas eksperimen.

Berdasarkan Gambar 2. dapat dilihat bahwa rata-rata nilai pretes kemampuan berpikir kritis siswa pada kelas kontrol dan kelas eksperimen memiliki perbedaan yang tidak terlalu jauh, hal ini menunjukkan kemampuan berpikir kritis awal siswa pada kelas kontrol dan kelas eksperimen adalah sama. Setelah dilaksanakan pembelajaran pada kelas kontrol dan kelas eksperimen menggunakan perlakuan yang berbeda, terjadi peningkatan nilai postes pada kedua kelas, 
diperoleh rata-rata nilai postes pada kelas eksperimen lebih tinggi dibandingkan dengan kelas kontrol. Perbedaan rata-rata nilai pretes dan postes pada masing-masing kelas mengindikasikan bahwa terdapat peningkatan kemampuan berpikir kritis pada masing-masing kelas. Adanya peningkatan kemampuan berpikir kritis siswa di kelas kontrol dan kelas eksperimen digambarkan dengan rata-rata $n$-Gain kemampuan berpikir kritis yang disajikan pada Gambar 3.

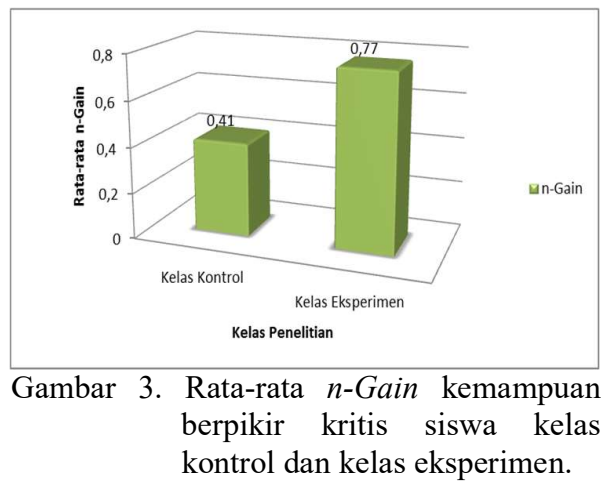

Berdasarkan Gambar 3, terlihat bahwa rata-rata $n$-Gain kemampuan berpikir kritis siswa pada kelas eksperimen lebih tinggi daripada rata-rata $n$-Gain kemampuan berpikir kritis siswa kelas kontrol. Rata-rata $n$-Gain kemampuan berpikir kritis siswa pada kelas eksperimen memiliki kategori "tinggi" sedangkan rata-rata n-Gain kemampuan berpikir kritis siswa pada kelas kontrol memiliki kategori "sedang". Hal tersebut menunjukkan bahwa pembelajaran berbasis isu sosiosaintifik dapat lebih meningkatkan kemampuan berpikir kritis siswa daripada pembelajaran tanpa berbasis isu sosiosaintifik.

Selanjutnya dilakukan analisis data keterlaksanaan pembelajaran berbasis isu sosiosaintifik. Keterlaksanaan pembelajaran berbasis isu sosiosaintifik yang diukur melalui penilaian terhadap keterlaksanaan pembelajaran berbasis isu sosiosaintifik yang berupa lembar observasi yang diisi oleh dua observer. Adapun hasil pengamatan observer terhadap keterlaksanaan pembelajaran berbasis isu sosiosaintifik pada kelas eksperimen dapat dilihat pada Tabel 6.

Tabel 6. Hasil Observasi Keterlasanaan Pembelajaran Berbasis Isu Sosiosaintifik

\begin{tabular}{|c|c|c|}
\hline $\begin{array}{l}\text { Perte- } \\
\text { muan }\end{array}$ & $\begin{array}{c}\text { Aspek } \\
\text { Pengamatan }\end{array}$ & $\begin{array}{c}\text { Persentase } \\
\text { Ketercapaian (\%) } \\
\text { Kelas Eksperimen }\end{array}$ \\
\hline 1 & $\begin{array}{l}\text { Kegiatan } \\
\text { Pendahuluan } \\
\text { Scientific } \\
\text { background }\end{array}$ & $\begin{array}{l}81,25 \% \\
77,5 \%\end{array}$ \\
\hline 2 & $\begin{array}{l}\text { Evaluation of } \\
\text { Information } \\
\text { Local. National, } \\
\text { and Global } \\
\text { Dimension } \\
\text { Decision } \\
\text { Making } \\
\text { Penutup } \\
\text { Pengelolaan } \\
\text { Waktu } \\
\text { Pata-rata }\end{array}$ & $\begin{array}{c}81,25 \% \\
87,5 \% \\
71,875 \%\end{array}$ \\
\hline 3 & $\begin{array}{l}\text { Kegiatan } \\
\text { Pendahuluan } \\
\text { Scientific } \\
\text { background } \\
\text { Evaluation of } \\
\text { Information } \\
\text { Local. National, } \\
\text { and Global } \\
\text { Dimension } \\
\text { Decision } \\
\text { Making } \\
\text { Penutup } \\
\text { Pengelolaan } \\
\text { Waktu } \\
\text { Rata-rata }\end{array}$ & $\begin{array}{c}93,75 \% \\
93,75 \% \\
84,375 \%\end{array}$ \\
\hline Rata- & $\begin{array}{l}\text { Rata-rata } \\
\text { ta keseluruhan } \\
\text { rtemuan }\end{array}$ & $\begin{array}{l}87,95 \% \\
84,33 \%\end{array}$ \\
\hline & Kategori & Sangat Tinggi \\
\hline
\end{tabular}

Keterlaksanaan pembelajaran berbasis isu sosiosaintifik di kelas eksperimen diamati oleh 2 observer pada setiap pertemuan. Berdasarkan data hasil observasi keterlaksanaan pembelajaran berbasis isu 
sosiosaintifik yang telah diperoleh, dapat dilihat bahwa rata-rata persentase keterlaksanaan pembelajaran berbasis isu sosiosaintifik pada kelas eksperimen di pertemuan pertama termasuk dalam kriteria "tinggi" sedangkan pada pertemuan kedua dan ketiga termasuk ke dalam kriteria "sangat tinggi". Persentase keterlaksanaan pembelajaran berbasis isu sosiosaintifik pada kelas eksperimen mengalami peningkatan pada setiap pertemuan. Hal ini menunjukkan bahwa pembelajaran berbasis isu sosiosaintifik telah terlaksana dengan baik.

Selain diamati keterlaksanaan pembelajaran berbasis isu sosiosaintifik pada kelas eksperimen, diamati pula aktivitas siswa pada setiap pertemuan. Adapun hasil pengamatan observer terhadap aktivitas siswa dapat dilihat pada Gambar 4.

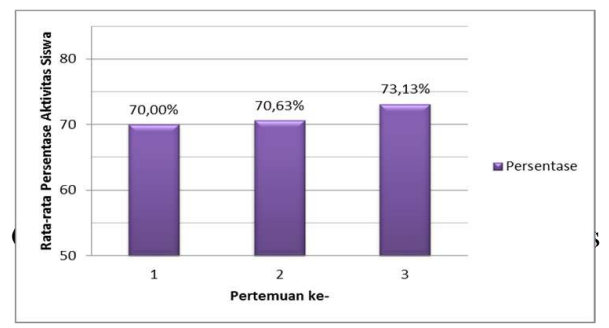

Gambar 4. Aktivitas siswa

Berdasarkan Gambar 4, dapat dilihat bahwa aktivitas siswa selama proses pembelajaran dengan menerapkan pembelajaran berbasis isu sosiosaintifik mengalami peningkatan setiap pertemuan. Dari hasil analisis diketahui bahwa pada pertemuan pertama, kedua dan ketiga kemampuan berpikir kritis siswa memiliki kriteria "tinggi". Rata-rata aktivitas siswa secara keseluruhan memiliki kriteria "tinggi". Hal ini menunjukkan bahwa terjadi peningkatan aktivitas siswa pada setiap pertemuan menggunakan pembelajaran berbasis isu sosiosaintifik. Hal ini sejalan dengan penelitian Yuliastini (2016) yang menunjukan bahwa penggunaan isu sosiosaintifik pada pembelajaran kimia dapat membantu guru memastikan semua siswa terlibat aktif dalam proses pembelajaran.

\section{Uji Hipotesis}

Pengujian hipotesis yang dilakukan oleh peneliti yaitu uji perbedaan dua rata-rata. Sebelum dilakukan uji perbedaan dua rata-rata menggunakan Indepndent Sample TTest, perlu dilakukan uji prasyarat yaitu uji normalitas dan uji homogenitas. Kedua uji tersebut dilakukan pada nilai pretes, postes, dan n-Gain. Pada uji normalitas untuk penelitian ini digunakan Kolmogorov Smirnov dan ShapiroWilk test. Kriteria uji pada uji normalitas yakni terima $\mathrm{H}_{0}$ jika nilai sig dari Kolmogorov- Smirnov dan Shapiro-Wilk test $>0,05$. Hasil perhitungan uji normalitas pada kelas eksperimen dan kelas kontrol disajikan pada Tabel 7 .

Tabel 7. Hasil Uji Normalitas Data Kemampuan Berpikir Kritis Siswa

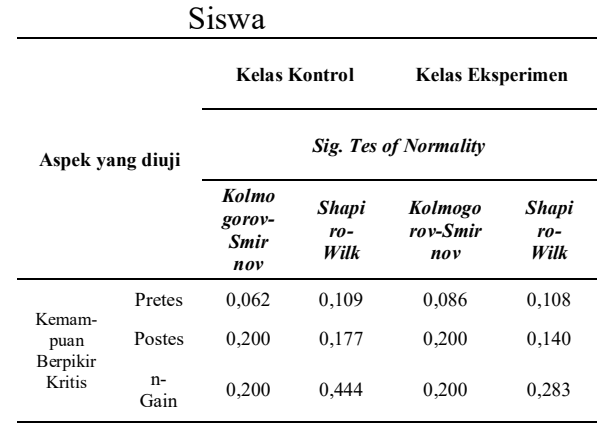

Berdasarkan Tabel 7. pada kelas eksperimen maupun kelas kontrol, untuk nilai pretes, postes, 
serta $n$-Gain memiliki nilai signifikasi lebih besar dari 0,05, dengan kriteria terima $\mathrm{H}_{0}$. Hal tersebut dapat dinyatakan bahwa kedua kelas tersebut memiliki sampel yang berasal dari populasi yang berdistribusi normal.

Uji homogenitas pada penelitian ini digunakan levene statistics. Kriteria uji untuk uji homogenitas yakni terima $\mathrm{H}_{0}$ jika nilai sig dari levene statistics $>0,05$ dan terima $\mathrm{H}_{1}$ jika nilai sig dari levene statistics $<0,05$. Hasil homogenitas untuk kedua kelas disajikan pada tabel 8 .

Tabel 8. Hasil Uji Homogenitas Data Kemampuan Berpikir Kritis Siswa

\begin{tabular}{ccc}
\hline \multirow{2}{*}{$\begin{array}{c}\text { Aspek yang } \\
\text { diuji }\end{array}$} & \multicolumn{2}{c}{ Kemampuan Berpikir } \\
& Kritis \\
\cline { 2 - 3 } & Nilai sig. & $\begin{array}{c}\text { Kriteria } \\
\text { Uji }\end{array}$ \\
\hline Pretes & 0,089 & Homogen \\
Postes & 0,916 & Homogen \\
n-Gain & 0,320 & Homogen \\
\hline
\end{tabular}

Berdasarkan Tabel 8. hasil uji yang diperoleh baik kelas eksperimen maupun kelas kontrol memiliki nilai sig. lebih besar dari 0,05 , dengan kriteria uji terima $\mathrm{H}_{0}$. Berdasarkan hal tersebut pada kelas eksperimen dan kontrol mempunyai varian kedua kelas yang homogen.

\section{Uji Perbedaan Dua Rata-Rata (Uji- t)}

Hasil uji normalitas dan uji homogenitas diperoleh hasil yang menunjukkan bahwa kedua sampel berdistribusi normal dan memiliki varians yang homogen, maka uji hipotesis parametrik dengan menggunakan uji perbedaan dua rata-rata yaitu uji Independent Sample T-Test.
Uji ini dilakukan untuk mengetahui apakah rata-rata nilai n-Gain kemampuan berpikir kritis siswa pada kelas eksperimen lebih tinggi dibandingkan rata-rata nilai $n$-Gain kemampuan berpikir kritis siswa pada kelas kontrol.

Hasil uji perbedaan dua ratarata $n$-Gain kemampuan berpikir kritis diperoleh nilai signifikansi sebesar 0,000 . Nilai signifikansi yang diperoleh kurang dari 0,05 pada uji-t n-Gain kemampuan berpikir kritis. Berdasarkan kriteria uji maka terima $\mathrm{H}_{0}$ dan tolak $\mathrm{H}_{1}$, yang berarti bahwa hipotesis yang berbunyi rata-rata $n$ Gain kemampuan berpikir kritis siswa pada materi larutan elektrolit dan non elektrolit yang diterapkan pembelajaran berbasis isu sosiosaintifik lebih tinggi dari ratarata $n$-Gain kemampuan berpikir kritis siswa dengan pembelajaran konvensional terbukti. Hal ini sejalan dengan penelitian yang dilakukan oleh Lathifah dan Susilo (2015) menyatakan bahwa pendekatan pembelajaran berbasis isu sosiosaintifik dapat meningkatkan kemampuan berpikir kritis. Hasil penelitian tersebut menunjukkan bahwa pendekatan pembelajaran berbasis isu sosiosaintifik berperan dalam kemampuan berpikir kritis peserta didik.

Tabel 9. Hasil Uji Perbedaan Dua Rata-rata Pretes-Postes Kemampuan Berpikir Kritis

\begin{tabular}{ccc}
\hline \multirow{2}{*}{ Kelas } & \multicolumn{2}{c}{ Kemampuan Berpikir } \\
Penelitian & \multicolumn{2}{c}{ Kritis } \\
\cline { 2 - 3 } & df & Nilai t \\
\hline Kontrol & 70 & $-15,854$ \\
Eksperimen & 70 & $-23,426$ \\
\hline
\end{tabular}

Selain melakukan uji perbedaan dua rata-rata $n$-Gain, dilakukan juga uji perbedaan dua rata-rata pretespostes kemampuan berpikir kritis 
siswa pada kelas kontrol dan kelas eksperimen. Adapun hasil uji perbedaan dua rata-rata pretes-postes pada kelas kontrol dan kelas eksperimen dapat dilihat pada Tabel 9.

Berdasarkan Tabel 9 telah diketahui nilai t pada kelas kontrol dan kelas ekperimen, dimana nilai t ini akan digunakan untuk perhitungan effect size pada kelas kontrol dan kelas ekperimen.

\section{Ukuran Pengaruh (Effect Size)}

Ukuran pengaruh penggunaan isu sososaintifik untuk meningkatkan kemampuan berpikir kritis diketahui melalui pengujian effect size. Adapun hasil perhitungan ukuran pengaruh ( $\mu$ ) disajikan pada Tabel 10.

Tabel 10. Hasil Perhitungan Effect Size

\begin{tabular}{ccc}
\hline \multirow{2}{*}{$\begin{array}{c}\text { Kelas } \\
\text { Penelitian }\end{array}$} & \multicolumn{2}{c}{ Kemampuan Berpikir } \\
\cline { 2 - 3 } & Effect Sizis & Kriteria \\
\hline Kontrol & 0,88 & Efek Besar \\
Eksperimen & 0,94 & Efek Besar \\
\hline
\end{tabular}

Berdasarkan Tabel 10 kelas eksperimen dengan menggunakan pembelajaran berbasis isu sosiosaintifik memiliki pengaruh "besar" dalam meningkatkan kemampuan berpikir kritis siswa pada materi larutan elektrolit dan non elektrolit. Begitu juga pada kelas kontrol, pembelajaran tanpa isu sosiosaintifik (pembelajaran secara konvensional) memiliki pengaruh "besar" dalam meningkatkan kemampuan berpikir kritis siswa pada materi larutan elektrolit dan non elektrolit. Besarnya kategori pengaruh pembelajaran berbasis isu sosiosaintifk pada kelas eksperimen dan pembelajaran secara konvensional pada kelas kontrol dapat dibedakan dari ketercapaian peningkatan $n$-Gain kemampuan berpikir kritis siswa. Tabel 13 juga memberikan informasi bahwa $94 \%$ kemampuan berpikir kritis siswa di kelas eksperimen dipengaruhi oleh pembelajaran berbasis isu sosiosaintifik dengan n-Gain tinggi . Pada kelas kontrol 88\% kemampuan berpikir kritis siswa dipengaruhi oleh pembelajaran secara konvensional dengan n-Gain sedang. Hal ini sejalan dengan penelitian yang telah dilakukan oleh Wilsa (2017) menyatakan bahwa model pembelajaran Problem Based Learning berbasis isu sosiosaintifik berpengaruh terhadap pengembangan kemampuan berpikir kritis, komunikasi tertulis dan verbal serta hasil belajar kognitif pada konsep keanekaragaan hayati. Selain itu, penelitian ini relavan dengan penelitian yang dilakukan oleh Putriana (2018), dimana penelitian Putriana menyatakan bahwa pembelajaran menggunakan isu sosiosaintifik berpengaruh besar dalam meningkatkan literasi kimia dan metakognisi siswa pada materi larutan elektrolit dan non elektrolit. Berdasarkan hal tersebut, dapat disimpulkan bahwa pembelajaran dengan menggunakan isu sosiosaintifik memiliki efek yang besar dalam meningkatkan kemampuan berpikir kritis siswa.

\section{SIMPULAN}

Berdasarkan analisis data hasil penelitian dan pembahasan dapat disimpulkan bahwa, pembelajaran berbasis isu sosiosaintifik berpengaruh dalam meningkatkan kemampuan berpikir kritis siswa pada materi larutan elektrolit dan non elektrolit. Ukuran pengaruh 
pembelajaran isu sosiosaintifik pada pembelajaran kimia dalam meningkatkan kemampuan berpikir kritis siswa berkriteria 'besar' sehingga berpengaruh positif dalam meningkatkan kemampuan berpikir kritis siswa pada materi larutan elektrolit dan non elektrolit. Indikator kemampuan berpikir kritis siswa yang sudah terlatih dengan baik yaitu pada indikator mendefinisikan istilah dan mempertimbangkan suatu definisi, sedangkan indikator kemampuan berpikir kritis siswa yang belum terlatih dengan baik yaitu pada indikator memfokuskan pertanyaan.

\section{DAFTAR RUJUKAN}

Abujahjouh, Y. M. 2014. The Effectiveness of Blended ELearning Forum in Planning for Science Instruction. Journal of Turkish Science Education, 11(4): 3-16.

Arikunto, S. 2006. Dasar-Dasar Evaluasi Pendidikan. Jakarta : Bumi Aksara.

Bassham G, W Irwin, H Nardone \& J M Wallace. 2010. Critical Thinking: A Student Introduction. 4th Edition. Mc Graw-Hill Company, Inc. On line at http://s3.amazonaws.com/engrad emyfiles/4008228113384505/St udents_Guide to_Critical_Think ing.pdf. diakses tanggal 25 Desember 2018.

Dincer, E. 2015. Effect of Computer Assisted Learning on Student's Achievement in Turkey: A Meta-Analysis. Journal of Turkish Science Education, 12(1): 99-108.
Ennis, R.H. 2011. The Nature of Critical Thinking: An Outline of Critical Thinking Dispositions and Abilities. Diakses pada tanggal 25 November 2018 dari http://faculty.education.illinois.e $\mathrm{du} /$ rhennis/documents/TheNatur eofCriticalThinking_51711_000. pdf.

Fraenkel, J. R., N. E. Wallen, \& H. H. Hyun. 2012. How to Design and Evaluate Research in Education (Eigth Edition). New York : McGrow-Hill.

Hake, R. R.1998. Interactiveengagement versus traditional methods: A six-thousand-student survey of mechanics test data for introductory physics courses. American journal of Physics, 66(1), 64-74.

Herlanti, Y. 2012. Pemanfaatan Media Sosial dalam Pembelajaran Sains Berbasis Isu Sosiosaintifik. Tabloid Aksara Edisi 54-56 Februari-April 2012. Tersedia di: https://yherlanti.wordpress.com/ 2012/02/10/pemanfaatanmediasosial-dalam-pembelajaransains-berbasis-issosiosaintifik/ (29 November 2018).

Holbrook, J. \& Rannikmae, M. 2009. The Meaning of Scientific Literacy. International Journal of Environmental \& Science Education, 4(3), 275- 288.

Lathifah, A. S., dan Susilo, H. 2015. Penerapan Pembelajaran Socioscientific Issues melalui Metode Simposium berbasis Lesson Study untuk Meningkatkan Kemampuan Berpikir Kritis Mahasiswa pada Mata Kuliah Biologi Umum. Dalam Prosiding Seminar Nasional Pendidikan Biologi, 919. 
OECD. 2016. Programme for International Student Assessment (PISA) Result From PISA 2015. OECD Publishing Online. Tersedia di: https://www.oecd. org/pisa/ PISA-2015-Indonesia.pdf. $\quad(10$ Desember 2018).

Osborne, J. 2005. The role of argument in Science Education dalam K. Boesma dalam M. Goedhart, O. De Jong, \& H. Eijkelhof (Ed.), Research and Quality of Science Education. Dordrecht, Nederlands: Spinger.

Putriana, Sunyono, Diawati, C. 2018. Pengaruh Penggunaan Isu Sosiosaintifik untuk Meningkatkan Kemampuan Metakognisi Siswa pada Materi Larutan Elektrolit dan NonElektrolit. Journal Pendidikan MIPA, 7(2): 5 - 12.

Sudjana, N. 2005. Metode Statistika. Bandung : Transito.

Sunyono, Wirya, I. W., Suyanto, E., dan Suyadi, G. 2009. Identifikasi Masalah Kesulitan dalam Pembelajaran Kimia SMA Kelas $\mathrm{X}$ di Propinsi Lampung. Journal Pendidikan MIPA, 10(2): 9-18.
Sunyono. 2012. Buku Model Pembelajaran Berbasis Multipel Representasi (Model SiMaYang). Anugrah Utama Raharja. Bandar Lampung.

Wilsa, A.W., Susilowati S. M. E. dan Rahayu E. S.. 2017. Problem Based Learning Berbasis SocioScientific Issue untuk Mengembangkan Kemampuan Berpikir Kritis dan Komunikasi Siswa. Journal of Innovative Science Education. Diakses pada tanggal 25 November 2018 dari http://journal.unnes.ac.id/sju /index.php/jise

Yuliastini, I. B., Rahayu, S., dan Fajaroh, F. 2016. POGIL Berkonteks Socio Scientific Issues (SSI) dan Literasi Sains Siswa SMK. Proseding Seminar Nasional Pendidikan IPA Pascasarjana UM, 1: 601-614.

Zeidler, D. L., Sadler, T. D., Simmons, M. L., \& Howes. E. V. 2005. Beyond STS: A Research-Based Framework for Socioscientific Issues Education. Wiley Inter Science, 89: 357377. 